\title{
Characterization of the Aqueous Fractions from Hydrotreatment and Hydrothermal Liquefaction of Lignocellulosic Feedstocks
}

\author{
Ellen Panisko ${ }^{a}$, Thomas Wietsma ${ }^{\mathrm{a}}$, Teresa Lemmon ${ }^{\mathrm{a}}$, Karl Albrecht ${ }^{\mathrm{a}}$, Daniel Howe ${ }^{\mathrm{a}^{*}}$ \\ Pacific Northwest National Laboratory, 902 Battelle Blvd., Richland, WA 99352, USA \\ Ellen.panisko@pnnl.gov, Thomas.wietsma@pnnl.gov, Teresa.lemmon@pnnl.gov, \\ Karl.albrecht@pnnl.gov, Daniel.howe@pnnl.gov
}

*Corresponding author

Daniel Howe

Development Engineer

Pacific Northwest National Laboratory, 902 Battelle Blvd., Richland, WA 99352, USA

e-mail: Daniel.howe@pnnl.gov

Phone: 1-509-372-4355

Fax: 1-509-372-1861

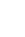
4 5

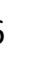
7 28 29 0 31

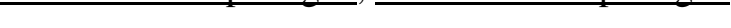


In this study the aqueous phases resulting from the hydrothermal liquefaction (HTL) of biomass and the hydrotreatment (HT) of fast pyrolysis bio-oils were analyzed via TC, COD, GC-MS, GC-FID, HPLC, and ICP-OES to determine the organic and inorganic species present and the quantitative amounts of each. This work is necessary to address a significant knowledge gap in the literature related to the aqueous phases from thermochemical processes. Results showed that water from the hydrotreatment of eight different bio-oils contained less than $1 \mathrm{wt} \%$ total carbon, in many cases less than $0.2 \%$. Negligible organic carbon was observed. HTL samples contained between 1-2 wt\% carbon. Due to the large volume of water added to the HTL feedstock and the dilute samples generated, this accounts for $34-45 \%$ of the total carbon sent to the reactor. The majority of this carbon was present as acids, with glycolic acid and acetic acid having the highest concentrations. Alcohols, specifically methanol and ethanol, were also present. Numerous ketones were observed, consisting of mainly acetone and cyclopenta-ones. The amount of the total carbon identified and quantified in the HTL samples ranged from $64-82 \%$. Inorganic species present in the HT samples were sodium, silicon, and sulfur. The highest levels of sulfur were observed in the grasses and agricultural residue (corn stover). The HTL samples exhibited much higher inorganic content, with very high levels of sodium and potassium. Alkali and alkali earth metals, as well as sulfur, were also present at levels high enough to raise concerns for the use of catalysts in downstream upgrading or reforming processes.

Key words: Hydrothermal liquefaction, hydrotreatment, bio-fuels, thermochemical conversions, wastewater analysis 


\section{Introduction}

As the global use of petrochemical fuels increases, the unsustainable nature of the current utilization trends is receiving greater attention. The concerns being raised cover a wide range of topics, including environmental, political, and economic [1-3]. In particular, the use of petrochemical fuels for the transportation industry has been highlighted. According to the most recent reports, $70 \%$ of all the petroleum consumed by the United States was used to produce liquid transportation fuels[4]. In light of this data, the use of renewable biomass feedstocks capable of generating infrastructure compatible liquid transportation fuels is receiving serious consideration [5]. In addition to biological conversion pathways such as fermentation to produce alcohols, thermochemical processes such as hydrothermal liquefaction (HTL) and fast pyrolysis (FP) have become a cornerstone of biofuels research [6].

The direct liquefaction of biomass to produce an intermediate known as bio-oil (when used for pyrolysis products) or biocrude (when referring to HTL products) has seen extensive research in the last several decades [7-10]. Two methods in particular have become the focus for the primary processing step, namely hydrothermal liquefaction and fast pyrolysis. Hydrothermal liquefaction is a process where the biomass is combined with water to form a slurry that is then pumped into a reactor operated in a condensed phase at medium temperature $\left(280-370^{\circ} \mathrm{C}\right)$ and high pressure $(10-25 \mathrm{MPa})$ with residence times typically in the range of 5 to 60 minutes [11]. The outlet stream includes the biocrude, solids consisting of primarily ash with small quantities of char, non-condensable gasses, and a distinct aqueous byproduct that is easily separated from the non-polar organic fraction (biocrude). Fast pyrolysis is a process where the biomass is rapidly heated (e.g. 2 seconds) to $\sim 500^{\circ} \mathrm{C}$ in an inert environment at ambient pressures. The resultant outlet stream contains a liquid aerosol, char, and non-condensable gasses [12]. The solids are removed from the product stream and the liquids are then condensed to give the final biooil product. Although the water content of the oil can be between $15-30 \%$, a separate aqueous fraction is generally not formed [13]. Regardless of the primary conversion pathway used, the resultant biooil/biocrude must undergo an upgrading process known as catalytic hydroprocessing (also referred to as 
hydrotreatment) that includes catalytic hydrodeoxygenation (HDO) and hydrocracking (HC) [8]. This step is necessary to reduce the oxygen and other heteroatom content of the bio-oil and make it compatible with petroleum refinery infrastructure for final processing into liquid fuels. Hydrotreating (HT) for pyrolysis bio-oil is often done as a two or three step process where the oil is passed over a noble metal catalyst at $\sim 220^{\circ} \mathrm{C}$, followed by a second catalyst bed containing cobalt and molybdenum operated at $400^{\circ} \mathrm{C}$. The outlet product stream is a mixture of upgraded fuel, non-condensable gasses, and a separate aqueous fraction [8]. HTL biocrude is thermally stable and can be hydrotreated in a single step. The aqueous yields when hydrotreating FP bio-oils can range from $40-60 \%$, while they are much lower for HTL biocrudes at 10-15\%. Hence the largest source of aqueous byproducts for the FP/upgrading pathway is after the HT stage, while for HTL/upgrading the largest source is immediately after the HTL step.

Although extensive research has been conducted on direct liquefaction and upgrading processes, the focus of the research is almost exclusively the quantity and quality of the bio-oil produced [7-10]. Very little data exists in the published literature examining the quantitative characterization of the organic compounds present in the aqueous phases formed during HTL of lignocellulosic materials or the HT of bio-oils. Villadsen's group in Denmark has developed an HPLC-TOF-MS analytical method that has shown the presence of specific fatty acids in the aqueous phase, along with pyrazine/pyridine, cyclopentanones, cyclopentenones, acids, amides, and furans [9]. However, the aqueous phases analyzed were primarily from the HTL of DDGS, with no lignocellulosic feedstocks used. This lack of data was highlighted in a report from Argonne National Laboratory where a key gap in the existing water footprint analysis was attributed to limited data availability, and "In particular, information on wastewater characterization of the new developing processes is limited in the public domain." [14]. And as mentioned in the conclusions of Villadsen's paper, “Only very few studies have previously analyzed organic compounds in the aqueous phase from HTL bio-oil production." [9]

To advance process economics and minimize environmental impact, the wastewater streams generated by the conversion process must be treated for discharge, anaerobically digested to produce 
methane, or catalytically upgraded/reformed into useful products prior to treatment. The use of catalytic hydrothermal gasification $(\mathrm{CHG})$ has shown great promise in the ability to convert organic carbon present in $\mathrm{HTL}$ aqueous streams to a medium BTU gas containing methane, $\mathrm{CO}$, and $\mathrm{CO}_{2}$. As reported by Doug Elliot's team at the Pacific Northwest National Laboratory (PNNL), chemical oxygen demand (COD) of the aqueous fraction from HTL of an algal feedstock was reduced by $98.8-99.8 \%$ under CHG [15]. The product gas had very little hydrogen or other higher hydrocarbons. The organic compounds present in the aqueous fraction from the HTL of lignocellulosic feedstocks can differ significantly from those found when using algal feedstocks, however. In addition to CHG, research is underway at PNNL to develop new processes capable of upgrading the aqueous phase organic compounds to liquid fuel range hydrocarbons, as well as reforming these compounds to provide some of the hydrogen required for bio-oil upgrading [16]. Maximizing the efficiency of the catalysts used in these processes requires characterization data not only of the types of compounds present, but their exact identity and quantity.

In order to begin filling a substantial knowledge gap in the published literature, refine and develop HTL process models and techno economic analyses (TEA), and enable the further development of aqueous phase upgrading and reformation research, aqueous samples from two different thermochemical conversion processes were quantitatively characterized. Hydrothermal liquefaction samples processed at various conditions and using either whole pine forestry residuals or corn stover as the feedstock were examined. Also studied were the aqueous fractions from the hydrotreatment of 8 different bio-oils generated from the fast pyrolysis of clean pine, whole pine, tulip poplar, hybrid poplar, corn stover, switchgrass, and 2 blends of the pure feedstocks.

\section{Materials and Methods}

\subsection{Hydrothermal Liquefaction (HTL)}


Hydrothermal liquefaction was conducted on four corn stover (C Stover) and four loblolly pine (L pine) forest product residual feedstocks at a nominal reactor temperature of $350^{\circ} \mathrm{C}$ and a nominal pressure of 20.7 MPa (3000 psi) using a continuous processing bench scale system described elsewhere [15]. A simplified schematic detailing where in the process the aqueous fraction originated is shown in Figure 1. Samples are named with an HTL, followed by either a CS for corn stover or a W for wood (L pine) and a number designating the specific experiment. Sodium carbonate was added to the feedstocks as a buffering agent prior to preparing the slurry at $1 \mathrm{wt} \%$. If sodium carbonate is not added and the $\mathrm{pH}$ drops below 4, condensation reactions may occur that lead to the formation of undesirable polymers such as polyfurfural. For recycled sample (CS8), the slurry was prepared with the aqueous fraction recovered from previous runs, which included small organic acids and alcohols. Total solids loading in the slurries varied from $9.6-14.5 \%$, with the remainder consisting of water. Slurries were pumped to system pressure, fed to a pre-heater, followed by a continuous stirred tank reactor (CSTR), and then passed through a plug flow reactor (PFR). The product stream was then passed through a filter maintained close to the reaction temperature in order to remove solid particulate matter, primarily consisting of ash. Post reaction, the liquefied product was separated into two phases (biocrude and aqueous byproduct) by gravity separation, and both phases were then sampled for analysis. COD was measured on a spectrophotometer according to the HACH 8000 method, ref. 40 CFR 136.3(a) [17]. Table 1 shows the processing conditions used to generate each individual sample.

\section{[Insert Figure 1 Here]}

\section{[Insert Table 1 Here]}

\subsection{Hydrotreatment $(H T)$}

Eight fast pyrolysis (FP) bio-oils were generated at the National Renewable Energy Laboratory (NREL) using feedstocks prepared by the Idaho National Laboratory (INL). The feedstocks consisted of 
clean pine (i.e. without bark), whole pine, hybrid poplar, tulip poplar, corn stover, switchgrass, a blend of equal weight proportions tulip poplar, whole pine, and switchgrass (blend 1), and a blend of equal weight proportions clean pine, hybrid poplar, and whole pine (blend 2). The fast pyrolysis was conducted in a $5.1 \mathrm{~cm}(2 \mathrm{in})$ fluidized bed reactor at a nominal temperature of $500^{\circ} \mathrm{C}$ and a residence time of 2 seconds.

The eight FP bio-oils were hydrotreated at PNNL in a two stage, continuous flow hydrotreater. The first stage utilized a sulfided noble metal catalyst on a carbon support, and the second stage used a sulfided cobalt/molybdenum catalyst on an $\mathrm{Al}_{2} \mathrm{O}_{3}$ support. Temperatures in the first catalyst bed were held at $220^{\circ} \mathrm{C}$, with temperatures in the second bed equal to $400^{\circ} \mathrm{C}$. Samples were taken every 6 hours, and the light oil phase was gravity separated from the aqueous phase. Aqueous samples from the steady state period, defined as the period where hydrotreater operation was stable and there was little difference in the density of the oil, were then combined for analysis. A simplified schematic detailing where in the process the aqueous fraction originated is shown in Figure 2. Samples are named with an HT followed by the identity of the feedstock used to generate the fast pyrolysis bio-oils.

\section{[Insert Figure 2 Here]}

\subsection{Inorganic Analysis}

Inorganic analysis was performed on a Perkin Elmer Optima 7300DV Inductively Coupled Plasma Optical Emission Spectrometer (ICP-OES) with the following configuration: Meinhard nebulizer, glass cyclonic spray chamber and $2.0 \mathrm{~mm}$ alumina injector. The instrument software version utilized was WinLab32 version 4.0. Calibration standards were prepared from certified standards, and verified with certified standards from a second source. Calibration standards and quality control standards were analyzed daily. Samples were filtered and diluted in DI water as necessary to be within the calibration range. The list of elements analyzed for include: $\mathrm{Ag}$ (328.068), $\mathrm{Al}$ (396.153), As (188.979), Ba (233.527), Ca (317.933), Co (228.616), Cr (267.716), Cu (327.393), Fe (238.204), K (766.490), Mg 
(285.213), Mn (257.610), Na (589.592), Ni (231.604), P (178.221), Pb (220.353), Re (197.248), Sr (421.552), V (310.230), Y (371.029), Zn (206.200), Mo (202.031), Si (251.611), Ti (334.940), W (207.912), Au (267.595), Pd (340.458), Pt (265.945), Rh (343.489), Ru (240.272), S (180.669), Sn (189.927), and $\operatorname{Zr}(343.823)$.

\subsection{Carbon Analysis}

Total carbon (TC) and inorganic carbon (IC) analysis was performed using a Shimadzu TOC5000A TOC analyzer equipped with a Shimadzu ASI-5000A autosampler and a non-dispersive infrared detector. Quantification ranges for TC were $500 \mathrm{ppb}$ to $4000 \mathrm{ppm}$, and for IC ranged from $500 \mathrm{ppb}$ to 5000 ppm. All samples were analyzed with 6 replicates and the results were averaged. Injections of 21 $\mu \mathrm{L}$ were analyzed in the TC using catalytically aided combustion oxidation at $680^{\circ} \mathrm{C}$. Inorganic carbon was measured separately by reacting the sample with phosphoric acid and measuring the resultant $\mathrm{CO}_{2}$.

\subsection{Gas Chromatography (GC) Analysis}

Initial GC/mass spectrometry (MS) analyses were performed on all HTL and HT samples to indentify the compounds present for the production of standards. Two custom commercial calibration mixtures were obtained from Restek Corporation. One mixture contained acetone, 2-butanone, cyclopentanone, 2-cyclopenten-1-one, 2-methylcyclopentanone, 2-methyl-2-cyclopenten-1one, gammavalerolactone, 3-methyl-2-cyclopenten-1-one, 2,3-dimethyl-2-cyclopenten-1-one, and gammabutrolactone at $0.1 \%$ (weight/weight) in water. The second standard mixture contained methanol, ethanol, 1-propanol, phenol, 4-ethylphenol, 2-methyoxyphenol, catechol, hyroquinone, orcinol, propylene glycol, and ethylene glycol at $0.1 \%$ (weight/weight) in water. Each solution was diluted with water gravimetrically to produce six point calibration ranges from approximately $0.005 \%$ to $0.1 \%$ 
(weight/weight). Quadruplicate measurements of all samples and each standard mixture at every calibration level by GC/ (MS) and GC/flame ionization detection (FID) was performed in a blocked randomized experimental design to control for instrument performance. Quadruplicate measurements follow NIST recommendations for statistical calibration (NIST/SEMATECH e-Handbook of Statistical Methods, http://itl.nist.gov/div898/handbook/, Chapter 2, Section 2.3.6.2 Data Collection). Our calibration and testing are tightly coupled in one design so we collected quadruplicate measurements across all treatment combinations to maintain statistical balance, avoiding confounding of treatment effects estimates, improving estimation of variance components and simplifying the statistical analaysis. An Agilent 7890 GC with 5875 MSD was configured with dual columns, both fused silica capillary columns with a stationary phase of 5\%-phenyl-methylpolysiloxane (HP-5MS, Agilent J\&W), 30 $\mathrm{m}$ long, $0.25 \mathrm{~mm}$ inner diameter, and $0.25 \mu \mathrm{m}$ film thickness. For both GC/MS and GC/FID methods $0.5 \mathrm{ul}$ of each sample was injected in at (split injection,50:1 ratio, inlet $270{ }^{\circ} \mathrm{C}$ ) onto the column which had an initial oven temperature of $40{ }^{\circ} \mathrm{C}$ that was held for 2 minutes, then the temperature was raised $10{ }^{\circ} \mathrm{C} /$ minute until reaching an oven temperature of $280{ }^{\circ} \mathrm{C}$. The final temperature was held for 2 minutes. Helium was used as a carrier gas (99.99\% pure). For GC/MS injections gas flow was set at $1.5 \mathrm{ml} / \mathrm{min}$. The mass spectrometer was configured in electron impact with an electron multiplier voltage of 1071 . The mass spectrometer source was set at $230{ }^{\circ} \mathrm{C}$ and the quadropole was set at $150{ }^{\circ} \mathrm{C}$. For GC/FID injections helium carrier gas flow was set at $2.18 \mathrm{ml} / \mathrm{min}$. The FID heater was set at $300^{\circ} \mathrm{C}$, hydrogen flow was 40 $\mathrm{ml} /$ minute, air flow was $400 \mathrm{ml} /$ minute, and makeup flow was $20 \mathrm{ml} /$ minute. Following identification of calibration compounds in HTL or HT aqueous sample by GC/MS using the NIST 08 spectral library, quantitation by GC/FID was performed utilizing peak areas obtained from the MSD ChemStation software after visual alignment of chromatograms. The average $\mathrm{R}^{2}$ value from the linear regression of calibrations utilized to generate data reported in this publication was 0.98 , with a standard deviation of 0.013. If there was an issue with a co-elutor or peak shape, quantitation by GC/MS was performed using peak areas of extracted ion chromatograms of a characteristic ion for that standard compound. 


\subsection{Liquid Chromatography (LC)Analysis}

Two custom commercial calibration mixtures were obtained from Restek Corporation. One mixture contained acetic acid and formic acid at 1.0\% (weight/weight) in water. The second standard mixture contained propionic acid at $0.1 \%$ (weight/weight) in water. A separate calibration solution was made using glycolic acid from Sigma-Aldrich (99\% pure) to approximately $1.0 \%$ (weight/weight) in water.The propionic acid solution was diluted with water gravimetrically to produce a six point calibration range from approximately $0.005 \%$ to $0.1 \%$, the other two calibration solutions were diluted with water to produce six point calibration ranges from approximately $0.05 \%$ to $1.0 \%$ (weight/weight). Quadruplicate measurements of all samples and standard mixture at each calibration level were performed in a blocked randomized experimental design to control for instrument performance. A $10 \mu$ injection of each sample was made onto an Aminex HPX-87H ion exclusion column, (Bio-Rad), 300 mm long, 7.8 $\mathrm{mm}$ inner diameter, equipped with a $30 \mathrm{~mm}$ long by $4.6 \mathrm{~mm}$ inner diameter quard column, using an Agilent 1100 LC system. The column was eluted isocratically with $0.005 \mathrm{M}$ sulfuric acid through a refractive index $(\mathrm{RI})$ detector. The RI detector optical unit temperature was set to $35^{\circ} \mathrm{C}$. Quantification was performed utilizing peak areas obtained from the ChemStation software after integration of chromatograms. The average $\mathrm{R}^{2}$ value from the linear regression of calibrations utilized to generate data reported in this publication was 0.99 , with a standard deviation of 0.001 .

\section{Results and Discussion}

As seen in Table 2, the amount of biogenic carbon reporting to the aqueous phase during hydrothermal liquefaction accounts for a significant portion of the carbon entering the reactor with the feedstock. Corn stover shows a slightly greater tendency to lose carbon into the aqueous phase with a range of $37-44 \mathrm{wt} \%$, compared to the range of $28-45 \%$ for the loblolly pine. The resultant aqueous 
phase is mildly acidic, with $\mathrm{pH}$ ranging from $4.4-5.4$. This is due to the hydrolysis of the cellulose and hemicellulose to form monomeric sugars, which are then further hydrolyzed to organic acids [18]. In addition, the presence of acetyl groups in certain sugars such as mono-acetylated galactose contributes to the formation of acetic acid, which contributes to the acidic $\mathrm{pH}$. The buffering effect of the $\mathrm{Na}_{2} \mathrm{CO}_{3}$ keeps the $\mathrm{pH}$ from going any lower than 4. COD of the aqueous fraction ranges from 41,000 - 77,000 $\mathrm{mg} / \mathrm{L}$. These values highlight the importance of efficient treatment methods when compared against raw municipal wastewater, with published COD ranges of $200-1,200 \mathrm{mg} / \mathrm{L}$ [19]. At these levels the use of municipal wastewater treatment plants is no longer an option without flow equalization, or dedicated treatment facilities at the processing facility must be employed.

\section{[Insert Table 2 Here]}

Hydrotreatment of the eight FP bio-oils shows that production of the aqueous fraction accounts for between $46-59 \%$ of the total liquid product, as seen in Table 3. Clean pine produces the least amount of water at $45.9 \%$, with corn stover producing the most at $59.4 \%$. It is important to note, however, that the bio-oil resulting from the FP of corn stover was biphasic with a distinct aqueous layer. While not common when processing woody feedstocks via FP this is not unusual for herbaceous feedstocks. Because both water and bio-oil were co-fed fed to the HT reactor for this feedstock the large amount of water collected is an expected result. Although approximately half of the final product from the FP/HT conversion pathway is water, this is the only aqueous output from the entire integrated process. As such, the total volume of water that would require treatment is significantly less than that found in HTL. In this study the HTL process resulted in 6-11 g Aq/g dry biomass in the outlet stream, while the FP/HT pathway resulted in $0.3-0.4 \mathrm{~g}$ Aq/g dry biomass. The $\mathrm{pH}$ of the HT aqueous phase is slightly basic, a result of the formation of soluble inorganic carbonate species through the decarbonylation and decarboxylation of aldehydes and carboxylic acids [20]. 


\section{[Insert Table 3 Here]}

While the aqueous fraction is a significant percentage of the total liquid product from the hydrotreatment of FP bio-oils, there is little to no organic carbon present. This is due to the nearly complete deoxygenation of the bio-oils via hydrodeoxygenation/dehydration, decarbonylation, and decarboxylation reactions that result primarily in non-polar aromatics or alkanes [20]. As shown in Figure 3, inorganic carbon was measured as equivalent to that of the total carbon for all eight samples. Inorganic carbon includes carbonates as well as dissolved $\mathrm{CO}_{2}$ and $\mathrm{CO}$. Total carbon in the pine and poplar samples, including the Blend 2 sample, was on average half as much as the switchgrass samples and a quarter of the corn stover. Carbon content in the aqueous phase as a function of feedstock has not been reported in the literature, although these values agree with the ranges reported by Doug Elliot's group at PNNL when bio-oils generated from eucalyptus and hybrid poplar were hydrotreated [21]. By contrast, very little inorganic carbon was found in the aqueous HTL samples regardless of feedstock, with the highest measured at $0.002 \%$. GC/MS analysis of all HT aqueous phases had no significant signal following the column void volume (data not shown). Aqueous phases from HT processes might be released or recycled with minimal treatment.

\section{[Insert Figure 3 Here]}

As discussed above, in HTL processing one quarter to nearly half of the carbon from the feedstock can end up in the aqueous phase. However, due to the amounts of water utilized in processing the final weight percent of carbon in the aqueous phase was less than $2 \%$ in the sample analyzed. Total carbon measurements ranged from 1.0 to $1.9 \%$, with corn stover aqueous phase samples averaging $30 \%$ more carbon than aqueous phases produced from wood. After initial GC/MS and GC/FID analysis to identify the most prevalent compounds in the sample, they were quantified by GC or LC methods. Figure 
4 shows the total carbon measured and the amount of carbon that was identified and quantified for all HTL samples. The data is summarized in Table 4.

For all HTL aqueous phases, glycolic acid was the most prevalent component. For corn stover samples, an average of $30 \%$ of the total carbon in the aqueous phase is contributed by glycolic acid. In wood aqueous phases the average drops to $25 \%$. Acetic acid is the next most prevalent component in all samples, however in corn stover aqueous phases it contributes an average of $20 \%$ to the total carbon present. Only $13 \%$ of the carbon in the wood aqueous phases is due to acetic acid. Formic acid contributes an average of $1 \%$ of carbon to the aqueous phases for all samples. Propionic acid on average is more prevalent in the HTL aqueous phases of wood; it constitutes an average of $3 \%$ of carbon versus $2 \%$ in corn stover samples. Overall, acids represent nearly half the carbon found in corn stover HTL aqueous phases and approximately $40 \%$ of that in wood samples.

Methanol is another component prevalent in all HTL aqueous phase samples. In wood samples it compromises an average of $10 \%$ of the total carbon, more than twice as much as in corn stover aqueous phases (average of 4\%). A similar trend is also observed with 2-methoxyphenol, it constitutes $1.7 \%$ of carbon from wood aqueous phases but only $0.6 \%$ that of corn stover. Phenol and 4-ethylphenol are both more prevalent in corn stover HTL aqueous phases. Phenol is an average of $1.3 \%$ of the carbon in corn stover samples and $0.7 \%$ that in wood. In all wood aqueous phase samples the 4-ethyl phenol was below the quantification limit. Carbon from corn stover aqueous phases is, on average, comprised of $0.6 \% 4-$ ethylphenol.

Hydroquinione, catechol, and orcinol were observed in samples but could not be quantified either due to instability in measured peak area or poor calibration. Orcinol was only observed in CS-5 and CS-7 samples. Catechol and hydroquinone was observed in all wood aqueous phases and in all corn stover samples except CS-2.

\section{[Insert Figure 4 Here]}




\section{[Insert Table 4 Here]}

Because both $\mathrm{CHG}$ and other upgrading/reforming technologies make use of catalysts whose performance can be affected by the presence of inorganic species, the mineral content of the aqueous phases must be characterized. As seen in Table 5, ICP-OES of the aqueous phases reveals that the hydrotreated samples contain very little inorganic material. This is to be expected given that the majority of inorganics present in the feedstock is removed as char during the FP step. Sodium and silicon account for nearly all of the non-sulfur species. Sodium is present in the original biomass feedstock, and due to its high solubility in water it is capable of persisting at some level through the entire process. Silicon is most often found in high levels in herbaceous and agricultural residue feedstocks, however it was observed at the highest levels in the poplars. This may be carryover from the hydrotreatment, where quartz (silicon) wool is used between the HT stages to support the catalyst bed. Sodium and silicon may potentially foul catalysts, and they represent a processing concern if vaporization is to be employed due to scaling. Of greater concern is the sulfur, which is known to poison catalysts especially noble metal catalysts. Because a sulfided catalyst is used in the HT process, carryover to the aqueous phase is extremely difficult to avoid and accounts for the moderately high levels observed. Because the raw biomass is heated and reacted in a condensed water phase, a large portion of the water soluble species will be extracted into the aqueous phase. Alkali and alkali earth metals make up the greatest fraction of the mineral content, with silicon levels comparable to that seen in the HT samples. Much of the cations found in wood and corn stover are a result of the dirt and dust present in the feedstocks. Sodium carbonate is added to the HTL feedstock as a buffer, and therefore the elevated 
sodium levels are not surprising. Although the sodium remains in solution, the majority of the carbonate is lost as $\mathrm{CO}_{2}$, resulting in the very low inorganic carbon content observed. Calcium is represented at a higher level when wood is used as a feedstock, while the potassium level is much higher when corn stover is employed. The higher concentrations of $\mathrm{K}$ in the corn stover samples may be due to the use of NPK fertilizers applied during the growing process. While it may be expected to also see higher levels of $\mathrm{P}$ as a result, most NPK fertilizers utilize an organic form of $\mathrm{P}$ that has a low solubility in water [22]. K levels are typically about 8 times higher than $\mathrm{P}$ levels in corn stover [23], so the low concentration of $\mathrm{P}$ in the aqueous phase is understandable. In addition, if both calcium and phosphorous are present in the aqueous phase they will precipitate out as calcium phosphate and be removed in the filtration step. Sulfur levels are considerably lower than those seen in the HT samples due to the lack of any sulfur containing catalysts. Sulfur levels are higher for the corn stover samples than the wood, again related to the use of sulfur rich fertilizers applied during the growing process that are incorporated into the corn stover as sulfur containing proteins.

\section{[Insert Table 5 Here]}

\section{Conclusions}

In this study the aqueous phases resulting from the hydrothermal liquefaction of biomass and the hydrotreatment of fast pyrolysis bio-oils were analyzed to identify and quantify the organic and inorganic species present. The negligible amount of organic carbon in the hydrotreater samples indicate that upgrading and/or reforming of this water will not generate significant amounts of fuel. HTL samples showed considerably more organic carbon, ranging from $1-2 \mathrm{wt} \%$ in the aqueous phase and representing $34-45 \%$ of the total carbon fed to the reactor. The main compounds identified and quantified were acids, alcohols, and ketones, although acids made up over $50 \%$ of the carbon identified. Identification of between $64-82 \%$ of the total carbon will substantially enhance the catalyst development, process 
modelling, and techno economic analysis needed to optimize the net carbon conversion efficiency in biorefineries.

\section{Acknowledgement}

This manuscript has been authored by Battelle Memorial Institute under Contract No. DE-AC0576RL01830 with the U.S. Department of Energy. The United States Government retains and the publisher, by accepting the article for publication, acknowledges that the United States Government retains a non-exclusive, paid-up, irrevocable, world-wide license to publish or reproduce the published form of this manuscript, or allow others to do so, for United States Government purposes.

The authors would like to thank Tyler Westover at INL and Daniel Carpenter at NREL for supplying the feedstocks and bio-oils used to generate the hydrotreater samples presented in this paper. We would also like to thank Andrew Schmidt at PNNL and the National Advanced Biofuels Consortium (NABC) for providing us with the HTL samples.

\section{References Cited}

[1] IPCC. Climate Change 2007: Synthesis Report section 2.4, Attribution of Climate Change. Intergovernmental Panel on Climate Change (IPCC); 2007.

[2] Watkins E. Watching the World: Iran Woos Latin America. Oil \& Gas Journal 1/16/2012;110.

[3] Jimenez-Rodriguez R, Sanchez M. Oil Price Shocks and Real GDP Growth: Empirical Evidence for Some OECD Countries. Applied Economics 2005;37:201.

[4] ElA. Annual Energy Outlook 2013 with Projections to 2040. Washington, DC: Department of Energy - U.S. Energy Information Administration; 2013.

[5] Logan BE. Extracting Hydrogen and Electricity from Renewable Resources: a roadmap for establishing sustainable processes. Environmental Science \& Technology 2004;38:160A.

[6] DOE. Bioenergy Technologies Office Multi-Year Program Plan. Washington DC: Department of Energy; 2013.

[7] Elliott DC, Hart TR, Neuenschwander GG, Rotness L, Zacher AH. Catalytic hydroprocessing of biomass fast pyrolysis bio-oil to produce hydrocarbon products. Environmental Progress \& Sustainable Energy 2009;28:441.

[8] Zacher AH, Olarte MV, Santosa DM, Elliott DC, Jones SB. A review and perspective of recent biooil hydrotreating research. Green Chemistry 2014;16:491. 
[9] Villadsen SR, Dithmer L, Forsberg R, Becker J, Rudolf A, Iversen SB, et al. Development and Application of Chemical Analysis Methods for Investigation of Bio-Oils and Aqueous Phase from Hydrothermal Liquefaction of Biomass. Energy \& Fuels 2012;26:6988.

[10] Toor SS, Rosendahl L, Rudolf A. Hydrothermal liquefaction of biomass: A review of subcritical water technologies. Energy 2011;36:2328.

[11] Behrendt F, Neubauer Y, Oevermann M, Wilmes B, Zobel N. Direct Liquefaction of Biomass. Chemical Engineering \& Technology 2008;31:667.

[12] Bridgwater A. Principles and practice of biomass fast pyrolysis processes for liquids. Journal of analytical and applied pyrolysis 1999;51:3.

[13] Czernik S, Bridgwater AV. Overview of Applications of Biomass Fast Pyrolysis Oil. Energy \& Fuels 2004;18:590.

[14] Wu M. Investigating Grey Water Footprint for the Production of Gasoline and Diesel from Biomass via Fast Pyrolysis. In: ANL, editor. Argonne IL; 2013.

407

[15] Elliott DC, Hart TR, Schmidt AJ, Neuenschwander GG, Rotness $\sqcup$, Olarte MV, et al. Process development for hydrothermal liquefaction of algae feedstocks in a continuous-flow reactor. Algal Research 2013;2:445.

[16] BETO. 2013 Peer Review Report: Review Panel Summary Report and Project Results. U.S. Department of Energy; 2014.

[17] Hach C. HACH 8000: Oxygen Demand, Chemical Using Reactor Digestion Method. 2010.

[18] Kruse A, Gawlik A. Biomass Conversion in Water at $330-410^{\circ} \mathrm{C}$ and $30-50 \mathrm{MPa}$. Identification of Key Compounds for Indicating Different Chemical Reaction Pathways. Industrial \& Engineering Chemistry Research 2002;42:267.

[19] Henze M. Wastewater treatment: biological and chemical processes: Springer; 2002.

[20] Mortensen PM, Grunwaldt J-D, Jensen PA, Knudsen K, Jensen AD. A review of catalytic upgrading of bio-oil to engine fuels. Applied Catalysis A: General 2011;407:1.

[21] Elliott D, Neuenschwander G. Liquid fuels by low-severity hydrotreating of biocrude. Developments in thermochemical biomass conversion: Springer; 1997, p. 611.

[22] Sawyer J, Mallarino A, Killorn R, Barnhart S. A general guide for crop nutrient and limestone recommendations in lowa. lowa State University Extension PM 1688. 2008.

[23] Henry WA, Morrison FB. Feeds and Feeding Abridged: The Essentials of the Feeding, Care, and Management of Farm Animals Including Poultry. 18th ed. Madison, MS: Morrison Publishing Company; 2013. 
Table 1. Processing conditions used to generate the HTL samples 


\begin{tabular}{|c|c|c|c|c|c|c|c|c|}
\hline Sample ID & W14 & W16 & W18 & W21 & $\mathrm{CS} 2$ & CS5 & CS7 & CS8 \\
\hline Recycle Rate & 0 & 0 & 0 & 0 & 0 & 0 & 0 & $2 x$ \\
\hline Feedstock & L. Pine & L. Pine & L. Pine & L. Pine & C Stover & C Stover & C Stover & C Stover \\
\hline Solids With & & & & & & & & \\
\hline $\begin{array}{l}\mathrm{Na}_{2} \mathrm{CO}_{3}(\mathrm{wt} \%) \\
\text { Solids } \\
\text { Without }\end{array}$ & 11.9 & 14.5 & 12.6 & 11.6 & 11.2 & 9.6 & 12.0 & 13.4 \\
\hline $\mathrm{Na}_{2} \mathrm{CO}_{3}$ (wt\%) & 10.9 & 13.5 & 11.6 & 10.6 & 10.2 & 8.6 & 11.0 & 12.4 \\
\hline $\begin{array}{l}\text { Reactor Temp } \\
\left({ }^{\circ} \mathrm{C}\right)\end{array}$ & 355 & 347 & 350 & 359 & 352 & 349 & 351 & 349 \\
\hline $\begin{array}{l}\text { Filter Temp } \\
\left({ }^{\circ} \mathrm{C}\right)\end{array}$ & 348 & 331 & 344 & 336 & 330 & 335 & 332 & 339 \\
\hline $\begin{array}{l}\text { Reactor } \\
\text { Pressure } \\
\text { (Mpa) }\end{array}$ & 20.8 & 20.7 & 20.5 & 21.0 & 19.8 & 20.6 & 20.8 & 20.8 \\
\hline $\begin{array}{l}\text { Space Velocity } \\
\text { (L/L/h) }\end{array}$ & 3.6 & 2.4 & 2.2 & 5.1 & 1.5 & 2.2 & 2.2 & 2.2 \\
\hline $\begin{array}{l}\text { Feed Rate } \\
(\mathrm{L} / \mathrm{h})\end{array}$ & 1.5 & 1.0 & 1.5 & 1.2 & 1.5 & 1.5 & 1.5 & 1.5 \\
\hline
\end{tabular}


Table 2. Normalized carbon partitioning to the oil, aqueous, gas, and solid phases during HTL of pine and corn stover feedstocks. The significant loss of carbon, mild acidity, and very high COD emphasize the need for efficient treatment or recovery methods. 


\begin{tabular}{|c|cccccccc|}
\hline Sample ID & W14 & W16 & W18 & W21 & CS2 & CS5 & CS7 & CS8 \\
\hline $\begin{array}{c}\text { Oil Yield - } \\
\text { Carbon (wt\%) }\end{array}$ & 60 & 50 & 64.1 & 43.9 & 51.9 & 42.9 & 46.0 & 44.0 \\
$\begin{array}{c}\text { Aqueous Yield } \\
\text { Carbon (wt\%) }\end{array}$ & 34 & 45 & 27.7 & 36.1 & 40.4 & 43.9 & 37.1 & 42.4 \\
$\begin{array}{c}\text { Gas Yield } \\
\text { Carbon (wt\%) }\end{array}$ & $\mathrm{NR}^{*}$ & $\mathrm{NR}^{*}$ & 8.2 & 6.0 & 6.4 & 12.0 & 14.7 & 10.6 \\
$\begin{array}{c}\text { Solid Yield } \\
\text { Carbon (wt\%) }\end{array}$ & $\mathrm{NR}^{*}$ & $\mathrm{NR}^{*}$ & 0.0 & 14.0 & 1.4 & 1.2 & 2.2 & 3.1 \\
Aqueous pH & 5.4 & 4.9 & 4.5 & 5.2 & 4.7 & 4.4 & 4.5 & 4.7 \\
COD (mg/L) & 41,000 & 55,000 & 52,000 & 40,000 & 64,000 & 54,000 & 55,000 & 74,000 \\
\hline
\end{tabular}

$\mathrm{NR}=$ Not Reported 
Table 3. Aqueous yields and $\mathrm{pH}$ of the aqueous phases from hydrotreatment of FP bio-oils. 


\begin{tabular}{|c|cc|}
\hline Feed & $\begin{array}{c}\text { Avg. Aq. Yield } \\
\text { (g Aq/g total feed) }\end{array}$ & $\mathrm{pH}$ \\
\hline Clean Pine & 0.459 & 8.3 \\
Whole Pine & 0.480 & 8.3 \\
Tulip Poplar & 0.463 & 8.5 \\
Hybrid Poplar & 0.477 & 8.5 \\
Switchgrass & 0.565 & 8.3 \\
Blend 1 & 0.522 & 8.4 \\
Blend 2 & 0.493 & 8.4 \\
Corn Stover & 0.594 & 8.8 \\
\hline
\end{tabular}


Table 4. Concentration, in weight percent, of major organic constituents identified in the aqueous phase of HTL samples. Average value is given with $95 \%$ confidence interval shown below in brackets. Some compounds were detected but were below the limit of quantification (BQL). 


\begin{tabular}{|c|c|c|c|c|c|c|c|c|}
\hline & HTL CS2 & HTL CS5 & HTL CS7 & HTL CS8 & HTL W14 & HTL W16 & HTL W18 & HTL W21 \\
\hline Acetic Acid & $\begin{array}{c}0.85 \\
{[0.81-0.90]}\end{array}$ & $\begin{array}{c}0.73 \\
{[0.71-0.76]} \\
\end{array}$ & $\begin{array}{c}0.85 \\
{[0.82-0.89]}\end{array}$ & $\begin{array}{c}1.08 \\
{[0.98-1.18]}\end{array}$ & $\begin{array}{c}0.44 \\
{[0.40-0.48]}\end{array}$ & $\begin{array}{c}0.47 \\
{[0.44-0.49]}\end{array}$ & $\begin{array}{c}0.50 \\
{[0.47-0.52]}\end{array}$ & $\begin{array}{c}0.36 \\
{[0.34-0.38]}\end{array}$ \\
\hline Formic Acid & $\begin{array}{c}0.078 \\
{[0.067-0.088]}\end{array}$ & $\begin{array}{c}0.080 \\
{[0.064-0.096]}\end{array}$ & $\begin{array}{c}0.058 \\
{[0.051-0.065]}\end{array}$ & $\begin{array}{c}0.061 \\
{[0.050-.073]}\end{array}$ & $\begin{array}{c}0.086 \\
{[0.074-0.098]}\end{array}$ & $\begin{array}{c}0.048 \\
{[0.036-0.060]}\end{array}$ & $\begin{array}{c}0.048 \\
{[0.037-0.059]}\end{array}$ & $\begin{array}{c}0.043 \\
{[0.033-0.053]}\end{array}$ \\
\hline Glycolic Acid & $\begin{array}{c}1.74 \\
{[1.69-1.79]}\end{array}$ & $\begin{array}{c}1.76 \\
{[1.70-1.83]}\end{array}$ & $\begin{array}{c}1.43 \\
{[1.39-1.46]}\end{array}$ & $\begin{array}{c}1.78 \\
{[1.75-1.81]}\end{array}$ & $\begin{array}{c}1.05 \\
{[1.02-1.09]}\end{array}$ & $\begin{array}{c}1.50 \\
{[1.48-1.53]}\end{array}$ & $\begin{array}{c}1.19 \\
{[1.17-1.22]}\end{array}$ & $\begin{array}{c}0.65 \\
{[0.63-0.67]}\end{array}$ \\
\hline Propionic Acid & $\begin{array}{c}0.12 \\
{[0.11-0.12]} \\
\end{array}$ & $\begin{array}{c}0.076 \\
{[0.074-0.077]} \\
\end{array}$ & $\begin{array}{c}0.11 \\
{[0.10-0.12]} \\
\end{array}$ & $\begin{array}{c}0.13 \\
{[0.11-0.14]} \\
\end{array}$ & $\begin{array}{c}0.12 \\
{[0.11-0.12]} \\
\end{array}$ & $\begin{array}{c}0.13 \\
{[0.13-0.14]} \\
\end{array}$ & $\begin{array}{c}0.13 \\
{[0.11-0.14]} \\
\end{array}$ & $\begin{array}{c}0.094 \\
{[0.088-0.10]} \\
\end{array}$ \\
\hline Ethanol & $\begin{array}{c}0.019 \\
{[0.016-0.022]} \\
\end{array}$ & $\begin{array}{c}0.10 \\
{[0.089-0.12]} \\
\end{array}$ & $\begin{array}{c}0.082 \\
{[0.076-0.088]} \\
\end{array}$ & $\begin{array}{c}0.072 \\
{[0.061-0.085]} \\
\end{array}$ & $\begin{array}{c}0.062 \\
{[0.056-0.069]} \\
\end{array}$ & $\begin{array}{c}0.053 \\
{[0.047-0.069]} \\
\end{array}$ & $\begin{array}{c}0.068 \\
{[0.059-0.078]} \\
\end{array}$ & $\begin{array}{c}0.025 \\
{[0.020-0.032]} \\
\end{array}$ \\
\hline 1-Propanol & BQL & $\begin{array}{c}0.016 \\
{[0.010-0.024]}\end{array}$ & $\begin{array}{c}0.017 \\
{[0.15-0.019]}\end{array}$ & $\begin{array}{c}0.015 \\
{[0.012-0.019]}\end{array}$ & $\begin{array}{c}0.016 \\
{[0.014-0.018]}\end{array}$ & $\begin{array}{c}0.015 \\
{[0.013-0.017]}\end{array}$ & $\begin{array}{c}0.016 \\
{[0.013-0.018]}\end{array}$ & $\begin{array}{c}0.0062 \\
{[0.0046-0.0084]}\end{array}$ \\
\hline Phenol & $\begin{array}{c}0.014 \\
{[0.012-0.016]}\end{array}$ & $\begin{array}{c}0.034 \\
{[0.030-0.038]}\end{array}$ & $\begin{array}{c}0.035 \\
{[0.033-0.036]}\end{array}$ & $\begin{array}{c}0.037 \\
{[0.031-0.046]}\end{array}$ & $\begin{array}{c}0.014 \\
{[0.013-0.016]}\end{array}$ & $\begin{array}{c}0.013 \\
{[0.012-0.014]}\end{array}$ & $\begin{array}{c}0.012 \\
{[0.012-0.013]}\end{array}$ & $\begin{array}{c}0.010 \\
{[0.0092-0.012]}\end{array}$ \\
\hline 2-Methoxyphenol & $\begin{array}{c}0.0090 \\
{[0.0077-0.010]} \\
\end{array}$ & $\begin{array}{c}0.019 \\
{[0.018-0.020]} \\
\end{array}$ & $\begin{array}{c}0.017 \\
{[0.016-0.018]} \\
\end{array}$ & $\begin{array}{c}0.015 \\
{[0.013-0.018]} \\
\end{array}$ & $\begin{array}{c}0.037 \\
{[0.032-0.042]} \\
\end{array}$ & $\begin{array}{c}0.033 \\
{[0.031-0.036]} \\
\end{array}$ & $\begin{array}{c}0.032 \\
{[0.030-0.035]} \\
\end{array}$ & $\begin{array}{c}0.030 \\
{[0.025-0.035]} \\
\end{array}$ \\
\hline Methanol & $\begin{array}{c}0.073 \\
{[0.067-0.079]} \\
\end{array}$ & $\begin{array}{c}0.20 \\
{[0.17-0.23]} \\
\end{array}$ & $\begin{array}{c}0.30 \\
{[0.26-0.33]} \\
\end{array}$ & $\begin{array}{c}0.24 \\
{[0.17-0.34]} \\
\end{array}$ & $\begin{array}{c}0.32 \\
{[0.28-0.37]} \\
\end{array}$ & $\begin{array}{c}0.46 \\
{[0.38-0.55]} \\
\end{array}$ & $\begin{array}{c}0.40 \\
{[0.31-0.51]} \\
\end{array}$ & $\begin{array}{c}0.24 \\
{[0.20-0.29]} \\
\end{array}$ \\
\hline 4-Ethylphenol & $\begin{array}{c}0.012 \\
{[0.010-0.014]} \\
\end{array}$ & $\begin{array}{c}0.017 \\
{[0.017-0.018]} \\
\end{array}$ & $\begin{array}{c}0.015 \\
{[0.014-0.016]}\end{array}$ & $\begin{array}{c}0.013 \\
{[0.011-0.016]}\end{array}$ & BQL & $\mathrm{BQL}$ & $\mathrm{BQL}$ & $\mathrm{BQL}$ \\
\hline Proplyene Glycol & $\begin{array}{c}0.0056 \\
{[0.0026-0.012]} \\
\end{array}$ & $\begin{array}{c}0.025 \\
{[0.023-0.027]} \\
\end{array}$ & $\begin{array}{c}0.015 \\
{[0.014-0.017]} \\
\end{array}$ & $\begin{array}{c}0.020 \\
{[0.018-0.021]} \\
\end{array}$ & $\begin{array}{c}0.010 \\
{[0.0084-0.011]}\end{array}$ & $\begin{array}{c}0.017 \\
{[0.014-0.021]} \\
\end{array}$ & $\begin{array}{c}0.011 \\
{[0.0086-0.016]}\end{array}$ & $\begin{array}{c}0.0060 \\
{[0.0049-0.0074]}\end{array}$ \\
\hline Ethylene Glycol & $\begin{array}{c}0.044 \\
{[0.036-0.055]}\end{array}$ & $\begin{array}{c}0.091 \\
{[0.024-0.34]}\end{array}$ & $\begin{array}{c}0.12 \\
{[0.090-0.17]}\end{array}$ & $\begin{array}{c}0.048 \\
{[0.047-0.049]}\end{array}$ & $\begin{array}{c}0.089 \\
{[0.084-0.094]}\end{array}$ & $\begin{array}{c}0.14 \\
{[0.098-0.22]}\end{array}$ & $\begin{array}{c}0.011 \\
{[0.077-0.16]}\end{array}$ & $\begin{array}{c}0.018 \\
{[0.018-0.019]}\end{array}$ \\
\hline Acetone & $\begin{array}{c}0.021 \\
{[0.020-0.023]} \\
\end{array}$ & $\begin{array}{c}0.050 \\
{[0.043-0.059]} \\
\end{array}$ & $\begin{array}{c}0.10 \\
{[0.087-0.11]} \\
\end{array}$ & $\begin{array}{c}0.071 \\
{[0.061-0.082]} \\
\end{array}$ & $\begin{array}{c}0.045 \\
{[0.037-0.055]} \\
\end{array}$ & $\begin{array}{c}0.076 \\
{[0.071-0.081]} \\
\end{array}$ & $\begin{array}{c}0.081 \\
{[0.071-0.093]} \\
\end{array}$ & $\begin{array}{c}0.034 \\
{[0.028-0.041]} \\
\end{array}$ \\
\hline 2-Butanone & $\begin{array}{c}0.018 \\
{[0.012-0.027]} \\
\end{array}$ & $\begin{array}{c}0.020 \\
{[0.013-0.031]}\end{array}$ & $\begin{array}{c}0.039 \\
{[0.028-0.054]} \\
\end{array}$ & $\begin{array}{c}0.029 \\
{[0.024-0.036]}\end{array}$ & $\begin{array}{c}0.017 \\
{[0.010-0.026]} \\
\end{array}$ & $\begin{array}{c}0.024 \\
{[0.018-0.032]} \\
\end{array}$ & $\begin{array}{c}0.026 \\
{[0.022-0.031]}\end{array}$ & $\begin{array}{c}0.012 \\
{[0.010-0.014]}\end{array}$ \\
\hline Cyclopentanone & $\begin{array}{c}0.0064 \\
{[0.0061-0.0067]} \\
\end{array}$ & $\begin{array}{c}0.017 \\
{[0.015-0.019]} \\
\end{array}$ & $\begin{array}{c}0.023 \\
{[0.019-0.026]} \\
\end{array}$ & $\begin{array}{c}0.021 \\
{[0.018-0.024]} \\
\end{array}$ & $\begin{array}{c}0.016 \\
{[0.014-0.018]} \\
\end{array}$ & $\begin{array}{c}0.020 \\
{[0.018-0.021]} \\
\end{array}$ & $\begin{array}{c}0.021 \\
{[0.018-0.025]} \\
\end{array}$ & $\begin{array}{c}0.013 \\
{[0.012-0.015]} \\
\end{array}$ \\
\hline 2-Cyclopenten-1-one & $\begin{array}{c}0.0058 \\
{[0.0055-0.0061]}\end{array}$ & $\begin{array}{c}0.016 \\
{[0.015-0.018]} \\
\end{array}$ & $\begin{array}{c}0.021 \\
{[0.020-0.022]} \\
\end{array}$ & $\begin{array}{c}0.012 \\
{[0.011-0.013]} \\
\end{array}$ & $\begin{array}{c}0.011 \\
{[0.0097-0.013]}\end{array}$ & $\begin{array}{c}0.015 \\
{[0.015-0.016]}\end{array}$ & $\begin{array}{c}0.020 \\
{[0.018-0.022]} \\
\end{array}$ & $\begin{array}{c}0.0057 \\
{[0.0051-0.0064]}\end{array}$ \\
\hline $\begin{array}{c}\text { 2-Methyl- } \\
\text { cyclopentanone } \\
\end{array}$ & DNQ & $\begin{array}{c}0.0055 \\
{[0.0050-0.0061]} \\
\end{array}$ & $\begin{array}{c}0.0061 \\
{[0.0056-0.0065]} \\
\end{array}$ & $\begin{array}{c}0.0062 \\
{[0.0055-0.0070]} \\
\end{array}$ & $\begin{array}{c}0.0059 \\
{[0.0047-0.0075]} \\
\end{array}$ & $\mathrm{BQL}$ & $\begin{array}{c}0.0054 \\
{[0.0042-0.0068]} \\
\end{array}$ & $\begin{array}{c}0.0056 \\
{[0.0048-0.0068]} \\
\end{array}$ \\
\hline $\begin{array}{l}\text { 2-Methyl-2-Cyclopenten- } \\
\text { 1-one }\end{array}$ & $\begin{array}{c}0.018 \\
{[0.018-0.018]} \\
\end{array}$ & $\begin{array}{c}0.035 \\
{[0.031-0.037]} \\
\end{array}$ & $\begin{array}{c}0.041 \\
{[0.040-0.042]}\end{array}$ & $\begin{array}{c}0.039 \\
{[0.038-0.040]}\end{array}$ & $\begin{array}{c}0.034 \\
{[0.032-0.036]}\end{array}$ & $\begin{array}{c}0.027 \\
{[0.026-0.028]}\end{array}$ & $\begin{array}{c}0.032 \\
{[0.028-0.036]}\end{array}$ & $\begin{array}{c}0.021 \\
{[0.019-0.023]} \\
\end{array}$ \\
\hline $\begin{array}{l}\text { 3-Methyl-2-Cyclopenten- } \\
\text { 1-one }\end{array}$ & $\begin{array}{c}0.010 \\
{[0.010-0.011]}\end{array}$ & $\begin{array}{c}0.023 \\
{[0.020-0.026]}\end{array}$ & $\begin{array}{c}0.029 \\
{[0.028-0.031]}\end{array}$ & $\begin{array}{c}0.030 \\
{[0.029-0.032]}\end{array}$ & $\begin{array}{c}0.015 \\
{[0.014-0.017]}\end{array}$ & $\begin{array}{c}0.020 \\
{[0.019-0.020]}\end{array}$ & $\begin{array}{c}0.020 \\
{[0.018-0.022]}\end{array}$ & $\begin{array}{c}0.013 \\
{[0.012-0.013]}\end{array}$ \\
\hline $\begin{array}{c}\text { 2,3-Dimethyl-2- } \\
\text { Cyclopenten-1-one }\end{array}$ & $\begin{array}{c}0.0074 \\
{[0.0072-0.0077]} \\
\end{array}$ & $\begin{array}{c}0.012 \\
{[0.011-0.013]} \\
\end{array}$ & $\begin{array}{c}0.015 \\
{[0.015-0.016]}\end{array}$ & $\begin{array}{c}0.020 \\
{[0.020-0.021]}\end{array}$ & $\begin{array}{c}0.0070 \\
{[0.0065-0.0075]}\end{array}$ & $\begin{array}{c}0.0074 \\
{[0.0072-0.0076]} \\
\end{array}$ & $\begin{array}{c}0.0083 \\
{[0.0076-0.0091]} \\
\end{array}$ & $\begin{array}{c}0.0071 \\
{[0.0067-0.0075]} \\
\end{array}$ \\
\hline$\gamma$-Butyrolactone & $\begin{array}{c}0.0055 \\
{[0.0043-0.0072]} \\
\end{array}$ & $\begin{array}{c}0.023 \\
{[0.021-0.026]}\end{array}$ & $\begin{array}{c}0.022 \\
{[0.021-0.024]}\end{array}$ & $\begin{array}{c}0.041 \\
{[0.036-0.047]} \\
\end{array}$ & $\begin{array}{c}0.017 \\
{[0.013-0.022]} \\
\end{array}$ & $\begin{array}{c}0.041 \\
{[0.039-0.042]} \\
\end{array}$ & $\begin{array}{c}0.034 \\
{[0.032-0.037]} \\
\end{array}$ & $\begin{array}{c}0.025 \\
{[0.021-0.029]} \\
\end{array}$ \\
\hline$\gamma$-Valerolactone & BQL & $\begin{array}{c}0.010 \\
{[0.0093-0.011]}\end{array}$ & $\begin{array}{c}0.011 \\
{[0.010-0.011]}\end{array}$ & $\begin{array}{c}0.019 \\
{[0.012-0.029]}\end{array}$ & $\begin{array}{c}0.014 \\
{[0.012-0.015]}\end{array}$ & $\begin{array}{c}0.022 \\
{[0.017-0.029]}\end{array}$ & $\begin{array}{c}0.020 \\
{[0.013-0.033]}\end{array}$ & $\begin{array}{c}0.012 \\
{[0.010-0.014]}\end{array}$ \\
\hline
\end{tabular}


Table 5. ICP-OES analysis of the aqueous fractions from hydrotreatment (HT) and hydrothermal liquefaction (HTL) in parts per million (ppm). 


\begin{tabular}{|c|ccccccccc|}
\hline \multicolumn{1}{|c}{} & Al & $\mathrm{Ca}$ & $\mathrm{K}$ & $\mathrm{Mg}$ & $\mathrm{Mn}$ & $\mathrm{Na}$ & $\mathrm{P}$ & $\mathrm{Si}$ & $\mathrm{S}$ \\
\hline HT-Clean Pine & $<0.8$ & $<0.8$ & $<2.0$ & $<0.8$ & $<0.8$ & 20 & $<0.8$ & 41 & 9.4 \\
HT-Whole Pine & $<0.8$ & $<0.8$ & $<2.0$ & $<0.8$ & $<0.8$ & 16 & $<0.8$ & 42 & 43 \\
HT-Tulip Poplar & $<0.8$ & $<0.8$ & $<2.0$ & $<0.8$ & $<0.8$ & 18 & $<0.8$ & 150 & 59 \\
HT-Hybrid Poplar & $<0.8$ & $<0.8$ & $<2.0$ & $<0.8$ & $<0.8$ & 20 & $<0.8$ & 130 & 88 \\
HT-Switchgrass & $<0.8$ & $<0.8$ & 2 & $<0.8$ & $<0.8$ & 15 & $<0.8$ & 24 & 180 \\
HT-Blend 1 & $<0.8$ & $<0.8$ & $<2.0$ & $<0.8$ & $<0.8$ & 10 & $<0.8$ & 13 & 140 \\
HT-Blend 2 & $<0.8$ & $<0.8$ & 2 & $<0.8$ & $<0.8$ & 11 & $<0.8$ & 19 & 65 \\
HT-Corn Stover & $<0.8$ & $<0.8$ & $<2.0$ & $<0.8$ & $<0.8$ & 14 & $<0.8$ & 81 & 570 \\
\hline HTL CS2 & 0.8 & 1.2 & 400 & $<0.8$ & $<0.8$ & 2070 & 3.5 & 79 & 15 \\
HTL CS5 & $<0.8$ & 17 & 830 & 2.6 & $<0.8$ & 6300 & $<0.8$ & 45 & 8.9 \\
HTL CS7 & 0.9 & 41 & 1070 & 2.9 & $<0.8$ & 5040 & $<0.8$ & 51 & 7 \\
HTL CS8 & 0.9 & 41 & 1400 & 6.6 & 1.8 & 6900 & 2.9 & 71 & 10 \\
HTL W14 & $<0.8$ & 43 & 150 & 29 & 8.2 & 4800 & $<0.8$ & 36 & 4.1 \\
HTL W16 & 0.8 & 85 & 180 & 53 & 19 & 5500 & $<0.8$ & 51 & 7.6 \\
HTL W18 & 1.2 & 92 & 160 & 47 & 22 & 3600 & $<0.8$ & 50 & 4.4 \\
HTL W21 & 0.9 & 41 & 120 & 25 & 4.8 & 3400 & $<0.8$ & 36 & 2 \\
\hline
\end{tabular}


Figure 1. Simplified schematic of the hydrothermal liquefaction process. Samples for analysis are taken after solids have been removed from the liquid product stream and separation of the bio-crude from the aqueous phase. 


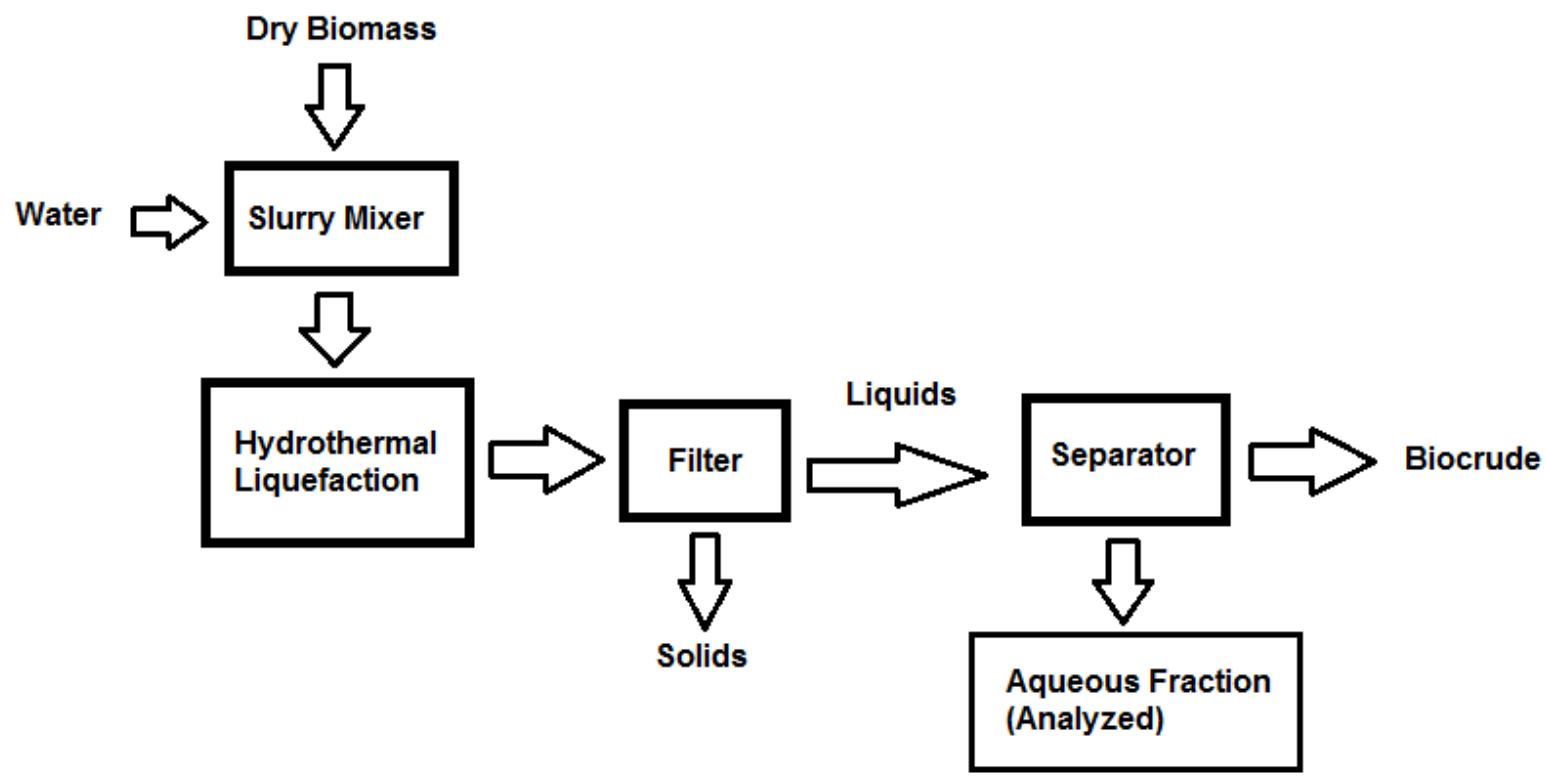


Figure 2. Simplified schematic of the hydrotreating process. Samples for analysis are taken after the upgraded oil (organic phase) and aqueous phase have been separated following hydrotreatment. 


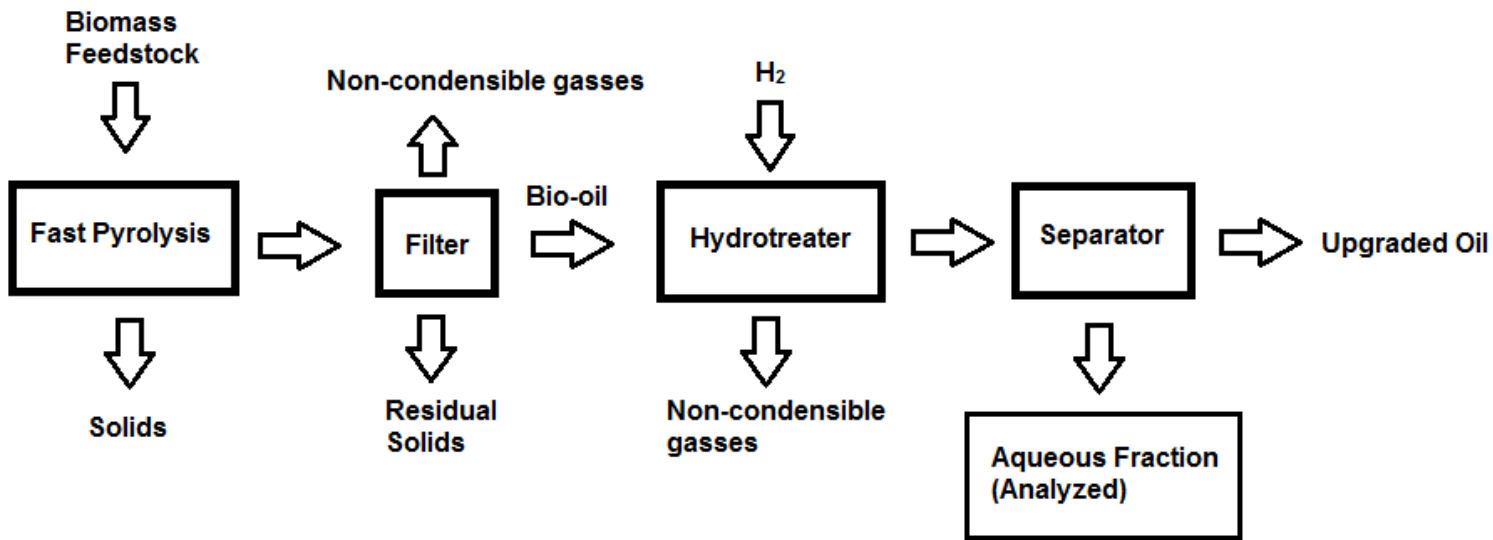


Figure 1. Analysis of HT samples shows the inorganic carbon (blue) with to overlap 95\% confidence intervals with total measured carbon (red) 


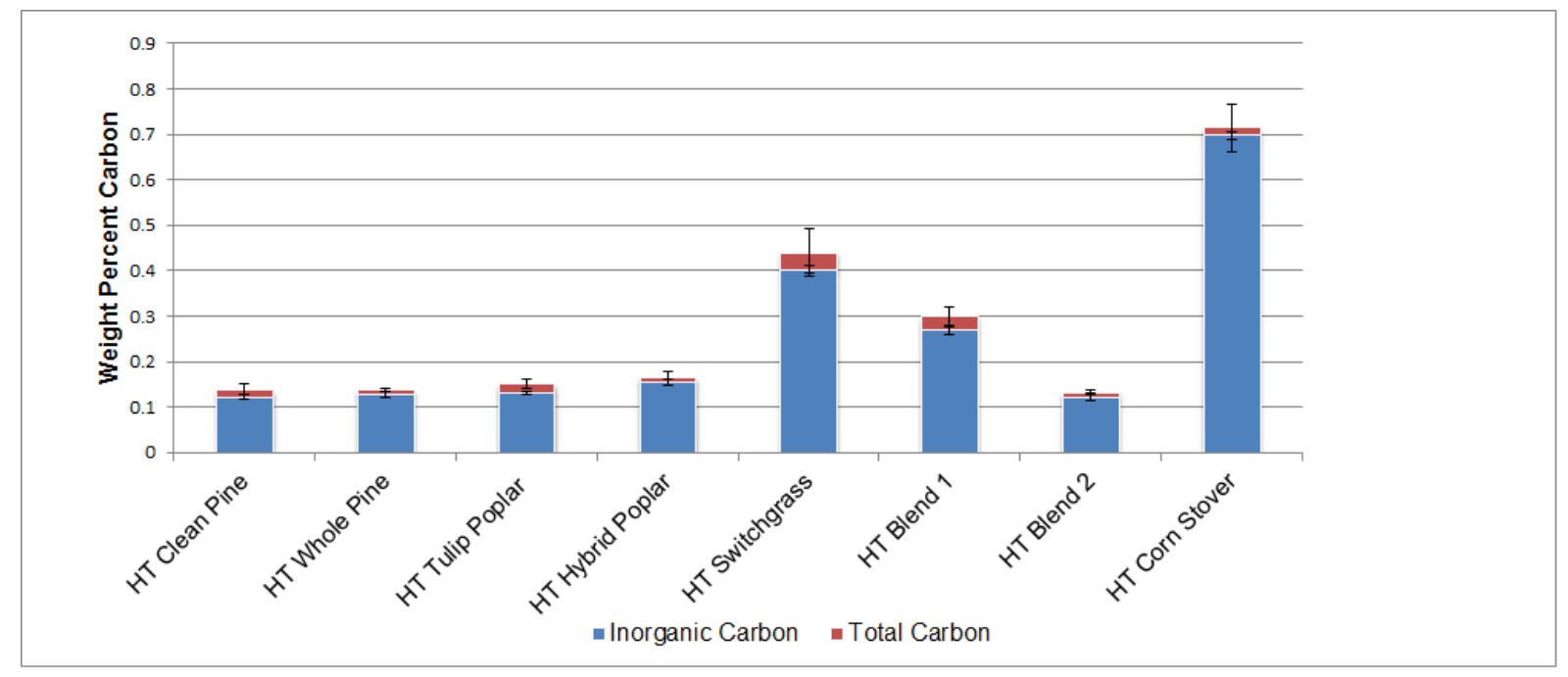


Figure 2. Carbon analysis of HTL samples shows that the majority of the carbon has been identified, ranging from $64-82 \%$ of the total carbon. The weight percent of carbon quantified as specific compounds (blue) is represented as a fraction of the total carbon present in each sample (red). Confidence intervals (95\%) are plotted for both measurements. 


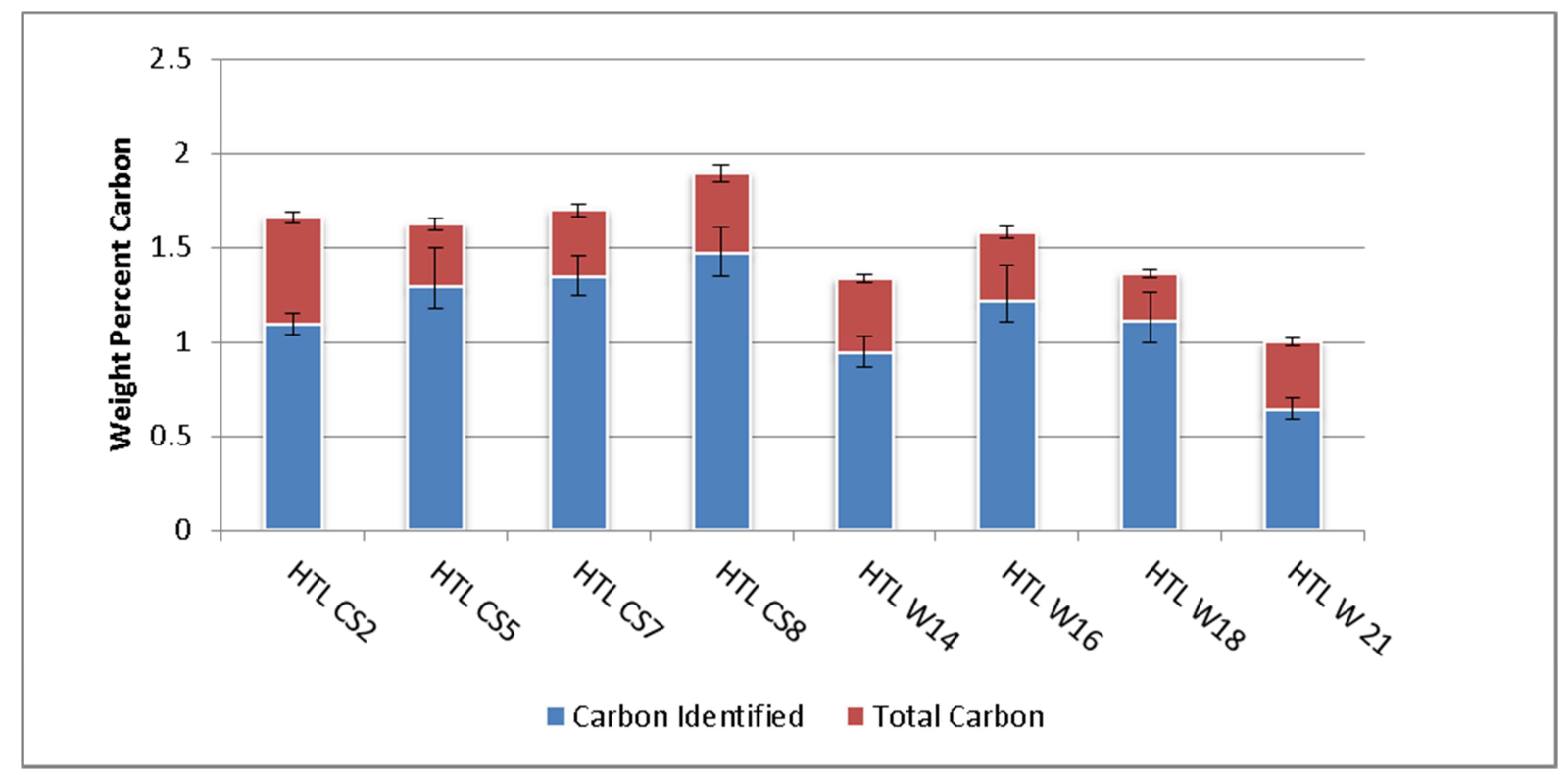

